\title{
Shio Dalam Tinjauan Values of Children
}

\author{
Shally Ocvitalia \\ Fakultas Psikologi, Universitas Surabaya \\ shallyocvitalia@gmail.com
}

\begin{abstract}
Every parent in the world will feel many things when having a child. The birth of a child will also make parents have new hopes for themselves, their families and also for the children themselves. Values of Children is one theory that can explain the expectations of parents when having children. This literature research aims to explain the relationship between chinese zodiac and values of children in society. The results of this literature study show there are two values of children towards parents based on a review of values of children. The categories included in social values are, a)Adult status \& social identity, b) Achievement, competence, creativity, c)Power, influence, effectiveness and d)Social comparison. Whereas the category included in economic value is economic utility and security in old age. Referring to the results of the literature research, a psychological approach can be applied in developing knowledge, understanding and insight into the relation of chinese zodiac and values of children to society in general. The implications of theory and practice can be discussed further.
\end{abstract}

Keywords : shio, chinese zodiac, values of children, parents profile

\section{Pendahuluan}

Dalam buku Myth In Primitive Psychology, mitos dalam komunitas merupakan bentuk primitif yang hidup, tidak hanya sebagai sebuah kisah yang diceritakan secara turun temurun tapi lebih kepada suatu realitas yang hidup. Mitos tidak bersifat fiksi seperti novel yang dibaca sehari- hari melainkan sebuah realitas yang dipercaya pernah terjadi dan terus berkontribusi pada kehidupan dan takdir manusia. Demikian pula dengan mitos yang ada pada sub suku bangsa di dunia yaitu suku Tionghoa. Suku Tionghoa di dunia mempunyai berbagai macam mitos yang secara disadari melekat dalam kehidupan manusia. Salah satu yang paling dipercaya adalah mengenai shio.

Dalam kehidupan sehari- hari, mayoritas orang Tionghoa di mempercayai dan memegang teguh shio dalam segala keputusan yang harus diambil. Seperti 
yang dimuat dalam buku Shēngxiào Wénhuà, shio sering kali digunakan dalam perhitungan peruntungan seseorang dalam satu tahun, untuk menentukan nama seseorang, untuk memilih tanggal pernikahan maupun tanggal pemakaman dan untuk membaca sifat seseorang. Tak jarang, sering kali shio juga digunakan sebagai patokan untuk menentukan jodoh yang "tepat".

Shio diyakini sebagai sesuatu yang mampu menentukan dan punya makna tersendiri bagi setiap orang yang mempercayainya. Sehingga hal itu akan menjadi sebuah value.

Dimana value (Oyserman, 2015) adalah struktur kognitif yang diinternalisasi dan mampu memandu pilihan dengan membangkitkan prinsip dasar akan benar dan salah serta menciptakan kemauan untuk membuat makna dan pola.

Pada pemahaman bagi masyarakat, shio yang sering dijadikan sebagai keberuntungan dan keagungan adalah shio naga. Di China, naga melambangkan seorang kaisar dan kekuatan. Ketepatan waktu yang ditentukan sangat menentukan akibat yang akan ditimbulkan. Karena shio sangat dipercaya dan digunakan dalam pengambilan keputusan, maka shio akan memunculkan suatu kepercayaan tersendiri yang mempengaruhi manusia. Bagi sebagian orang yang mempercayai akan keagungan orang yang lahir di tahun naga akan memunculkan keyakinan bahwa orang tersebut akan menjadi orang yang membawa keberuntungan. Keberuntungan tersbut bisa diartikan pada banyak hal, seperti keberhasilan dalam berkeluarga, dalam bekerja, dan dalam hal lainnya. Sehingga banyak orang tua yang merencanakan kelahiran anaknya di tahun naga.

Naga yang digambarkan dalam mitologi adalah binatang konseptual yang ada dan hidup dalam kesadaran massal di dunia. Budaya naga "tertanam" sangat dalam pada beberapa negara bagian Timur, seperti China, Korea, Jepang dan negara Asia lain dan dianggap sebagai domain praktek budaya. Praktek budaya yang dimaksud adalah praktek yang menciptakan kesadaran massa yang menopang sebagai lintasan struktur sosial yang layak dan digambarkan secara material dan tidak material dari sejarah kuno. Dalam masyarakat yang terlibat dan percaya, praktek budaya ini tidak pernah diremehkan atau diabaikan . 
Shio naga mempunyai banyak nilai atau value. Jika dikaji dalam persepektif psikologi ada berbagai macam teori yang bisa digunakan, salah satunya adalah value of children. Mengenai bagaimana seorang anak mampu memenuhi harapan dan keinginannya dalam keluarga. Dan dapat dikatakan, bahwa nilai anak memiliki kaitan erat dengan fungsi seorang anak bagi orang tua.

Kebudayaan Tiongkok berpusat pada keseimbangan yin dan yang. Dalam buku Handbook of Chinese Mythology, dikatakan bahwa yin dan yang adalah dua prinsip yang bertentangan di alam, yang pertama mewakili feminin dan maskulin serta negatif dan positif. Demikian juga menyangkut shio, dari 12 shio yang ada, akan dibagi menjadi yin dan yang.

Yin terbagi dalam shio tikus, macan, naga, kuda, monyet dan anjing. Sedangkan yang terbagi dalam kerbau, kelinci, ular, kambing, ayam dan babi. Berdasarkan dari elemen yin dan yang dalam shio saja sudah cukup untuk mempengaruhi kecemasan bagi seseorang. Sedangkan shio memiliki gambaran sangat luas dan memiliki stereotipe dalam masyarakat yang mempercayainya, sehingga membuat manusia menjadi cemas dan mengarahkan manusia pada suatu perilaku tertentu. Setiap shio adalah seimbang, yang masing- masingnya memiliki kelebihan dan kekurangan. Tidak ada satupun shio yang sangat beruntung atau shio yang dipenuhi dengan kesialan, karena semua shio itu baik.

Penelitian ini bertujuan untuk menjelaskan hubungan antara shio dan values of children pada masyarakat. Selain itu supaya dapat bermanfaat untuk mengembangkan pengetahuan, pemahaman dan wawasan akan keterkaitan shio dengan values of children pada masyarakat secara umum.

Penelitian ini menggunakan metode kajian literatur dengan jenis systematic mapping study. Peneliti memilih penelitian - penelitian sebelumnya berupa buku dan jurnal yang sesuai dengan tema shio yang diteliti dan values of children, dengan klasifikasi tahun mulai 1991 hingga tahun 2010. 


\section{Diskusi}

\section{Shio}

Dalam buku Shio \& Feng Shui (Tjong Liang Chen dalam Santosa, 2018) mengenal shio sebagai bagian dari Chinese Metaphysics, dimana shio merupakan simbol binatang Tiongkok yang dapat digunakan sebagai tolak ukur untuk mengetahui kepribadian, kesehatan, karier, asmara dan pergaulan seseorang. Shio berasal dari bahasa mandarin yang berarti "mirip", "persis" atau "seperti".

Dalam buku Common \& Knowledge about Chinese Culture (2007), dikatakan bahwa setiap manusia yang lahir akan memiliki lambang shio yang mewakilinya. Ada sebuah pepatah Cina kuno yang mengatakan bahwa "inilah binatang yang tersembunyi di dalam lubuk hatimu". Binatang tahun kelahiran akan mempengaruhi kepribadian dan kehidupan seseorang serta alam semesta dan seluruh isinya. Dalam kepercayaan masyarakat Tiongkok, shio terbagi menjadi 12 macam, yaitu tikus, kerbau, macan, kelinci, naga, ular, kuda, kambing, monyet, ayam, anjing dan babi. Masing- masing shio tersebut mewakili atau menggambarkan tingkah laku setiap orang. Misalnya, seseorang yang mempunyai shio kerbau, dapat dikatakan akan memiliki tingkah laku yang mirip, persis atau seperti kerbau.

\section{Shio dalam Values of Children}

Menurut Hoffman dan Hoffman (1973), diacu dalam Santrock (2007), nilai anak adalah harapan orang tua terhadap anak yang terdiri dari nilai psikologi (anak sebagai sumber kepuasan), nilai sosial (anak sebagai pencegah perceraian meningkatkan status sosial keluarga) dan anak sebagai nilai ekonomi yaitu sebagai investasi jangka panjang untuk meningkatkan ekonomi keluarga di masa yang akan datang. Hoffman (1973) memberikan komponen dalam values of childen, antara lain:

a) Adult status and social identity ( status orang tua dan identitas sosial) Memiliki anak sering dipandang sebagai pencapaian status orang tua dan penerimaan penuh dalam masyarakat. Kedudukan sebagai orang tua secara tradisional menjadi hasil dari proses sosialisasi. 
b) Expansion of the self, ties to a larger entity, immortality (ekspansi diri,ikatan dengan entitas yang lebih besar dan keabadian)

Aspek kehidupan yang mengganggu adalah cepatnya waktu berlalu. Dari ketidaktahuan nyata dari eksistensi individu dalam konteks waktu dan ruang telah menyebabkan banyak orang merasakan kebutuhan untuk menempatkan diri di luar masa hidup diri sendiri atau makna yang lebih besar dari kehidupan. Kebutuhan ini adalah apa yang disoroti oleh masyarakat urban, industri dan sekuler. Di sisi lain, agama telah menjadi jawaban bagi banyak orang, barangkali secara khusus dimana agama memberikan keyakinan pada kehidupan setelah kematian dan keabadian jiwa. Tetapi dengan mempunyai anak akan menjadi cara untuk memenuhi kebutuhan ini

1) Morality (moralitas)

Menjadi orang tua, atau khususnya dengan menjadi ibu, sering disamakan dengan kebajikan. Tanggung jawab dan kepedulian orang tua terkadang dilihat sebagai keterlibatan pada arah impulsif dan oregentrisme. Dalam beberapa kasus, agama seseorang dapat secara eksplisit mengikat orang tua pada moralitas, tetapi bahkan pengaruh sekuler seperti media massa dan persyaratan peran mutlak yang dapat menghubungkan orang tua dengan konsep altuirisme dan nilai moral yang lebih besar

2) Primary group tie and affection (ikatan dan kasih sayang)

Nilai afiliatif anak telah dilaporkan secara khusus dan penting dalam berbagai budaya. Pentingnya keluarga inti sebagai benteng dalam melawan impersonalisasi masyarakat modern telah dicatat oleh sosiolog dan psikolog selama bertahun- tahun. "Menghindari kesepian" dan "supaya ada yang menemani" telah disebut sebagai alasan memiliki anak dan untuk memiliki keluarga besar

3) Stimulation, novelty, fun (stimulasi, pengalaman baru dan kesenangan) Salah satu kebutuhan manusia adalah memiliki perubahan, pengalaman baru dan stimulasi. Anak- anakdapat memenuhi kebutuhan manusia ini dengan berbagai cara. Munculnya bayi itu sendiri termasuk dalam Jurnal Insight Fakultas Psikologi Universitas Muhammadiyah Jember | 116 
perubahan, dan pengalaman baru sedangkan untuk pertumbuhannya selama bertahun-tahun yang terus berkembang menunjukkan perubahan secara konstan. Anak- anak membawa rangsangan dan aktivitas, dan disamping itu, anak dilihat sebagai sumber kebahagiaan dan sumber sukacita.

4) Achievement, competence, creativity (pencapaian, kompetensi dan kreatifitas)

Orang tua dapat memperoleh rasa pencapaian, kompetensi dan kreatifitas dengan memiliki anak, bukan hanya dari proses fisik yang melahirkan anak tetapi juga memenuhi tantangan untuk mengamati respon anak. Mempunyai anak yang berprestasi dapat dilihat sebagai sumber kepuasan dalam pencapaian, khususnya bagi orang tua yang memiliki kebutuhan untuk mencapai prestasi tinggi.

5) Power, influence, effectiveness (kekuatan, pengaruh dan keefektifan)

Sebuah gagasan bahwa anak- anak bisa memberikan rasa kekuasaan bagi orang tuanya, terlebih pada orang tua yang menempati status rendah di masyarakat. Hal ini dapat menjadi kebutuhan yang diharapkan dapat terpenuhi setelah memiliki anak

1) Social comparison (perbandingan sosial)

Perbandingan akan status sosial yan gbelum bisa dicapai oleh orang tua yang tidak berstatus tinggi akan memiliki kebutuhan untuk bisa diakui secara sosial dengan kehadiran anaknya yang diharapkan mampu meningkatkan derajat status keluarganya

2) Economic utility, security in old age (utilitas ekonomi dan aman di usia tua)

Nilai utilitas ekonomi anak sering dipelajari dan dikaitkan dengan negara yang per tahunnya memiliki angka kelahiran tinggi. Di negara maju seperti Amerika Serikat, dengan dominasi populasi di perkotaan dengan jaminan sosial yang disponsori pemerintah, anak- anak memiliki utilitas ekonomi kemungkinan lebih kecil daripada tempat lain. 


\section{Analisis Diskusi}

Berdasarkan hasil penelitian literatur yang dilakukan oleh peneliti, dalam jurnal "Creating New Traditions in Modern Chinese Population : Aiming For Birth in Year of the Dragon" oleh Daniel M. Goodkind (1991) berpendapat bahwa secara persuasif bahwa keyakinan superstitious dalam hubungan antara nasib baik dan naga telah ada selama ribuan tahun, selain itu keyakinan bahwa memiliki anak di tahun naga akan memberikan nasib kepada orang tua yang relatif baru. Anak yang lahir di tahun naga akan lebih beruntung, lebih bersinar, lebih kuat, dan lebih berhasil dibandingkan dengan anak yang lahir di tahun lain. Dengan demikian, kelahiran di tahun naga dipahami sebagai ciptaan yang relatif baru yang muncul dari rangkaian terpisah dan keyakinan yang lebih kuno.

Ditinjau dari values of child, terdapat beberapa komponen yang menunjukkan bahwa orang tua yang menjadi sampel penelitian membutuhkan power, influence, effectiveness karena orang tua anak yang lahir di tahun naga bisa berhasil dan mempunyai kekuatan untuk mengubah nasib orang tuanya . Dengan mengubah nasib orang tua, sama artinya bahwa orang tua mengahrapkan si anak untuk mampu membuatnya tinggi dalam social comparison supaya dapat diakui oleh masyarakat karena keberhasilan anaknya. Orang tua juga menginginkan anaknya supaya bias berhasil dan mampu membawa orang tuanya lebih stabil dalam perekenomian yang termasuk dalam economic utility, security in old age.

Dalam jurnal "Does Fortune Favor Dragons?" oleh Johnson \& Nye (2010), dikatakan bahwa banyak orang Asia yang percaya bahwa anak yang lahir di tahun naga (setiap 12 tahun sekali) akan memiliki keberuntungan yang besar, kemungkinan besar akan berhasil di sekolah dan memiliki kehidupan yang lebih baik. Penelitian dilakukan pada imigran Asia yang tinggal di Amerika dengan menggunakan data Curent Population Surveys tahun 2000, 2004, 2006, dan 2008. dari Sensus AS

Oleh karena itu peneliti menganalisa akan keyakinan yang dipegang secara luas di kalangan orang Asia bahwa anak- anak yang lahir di tahun naga lebih unggul. Selain itu, berdasarkan penelitiannya, diketahui bahwa ibu- ibu Asia yang memiliki anak di tahun naga lebih berpendidikan, lebih kaya dan lebih tua Jurnal Insight Fakultas Psikologi Universitas Muhammadiyah Jember | 118 
bila dibandingkan dengan ibu- ibu Asia yang memiliki anak yang lahir di tahun selain naga.

Hal ini menunjukkan bahwa kepercayaan pada superioritas yang lebih besar dari anak- anak yang lahir di tahun naga adalah pemenuhan diri sendiri karena karakteristik demografi yang terkait dengan orang tua yang mampu menyesuaikan strategi melahirkan supaya memiliki anak di tahun naga.

Ditinjau dari values of child, terdapat beberapa komponen yang menunjukkan bahwa orang tua yang menjadi sampel penelitian membutuhkan keberhasilan anaknya di bidang sekolah supaya mampu mencapai pencapaianpencapaian yang menjadi kebutuhan orang tuanya dan masuk dalam kategori achievement, competence, creativity dan orang tua ingin anaknya mempunyai kehidupan yang lebih baik dari sebelumnya dan masuk dalam kategori economic utility, security in old age supaya dengan keberhasilannya mampu membawa orang tua untuk lebih stabil secara ekonomi

Dalam jurnal "The Influence of the Chinese Zodiac on Fertility in Hongkong SAR” oleh Yip, Lee dan Cheung (2002), dijelaskan bahwa bagaimana preferensi zodiak Cina yang mempengaruhi kesuburan (fertility) antara tahun 1976 - 2000. Tradisi dan keyakinan Cina dapat memberikan pengaruh pada keputusan untuk menentukan tanggal pernikahan. Preferensi tahun naga memberikan pengaruh pada kesuburan populasi masyarakat Cina modern melalui kelahiran-waktu zodiak. Dalam penelitian, ditinjau dari jumlah kelahiran pada tahun 1988 - 2000 di Hongkong.

Pada tahun naga $(1976,1988$, dan 2000) terjadi peningkatan dalam kelahiran anak dibandingkan dengan tahun- tahun sebelumnya. Preferensi tahun kelahiran di tahun naga adalah pengambilan keputusan yang rasional dari pihak orang tua dengan perspektif supaya anaknya lebih berkualitas dan mempunyai masa depan yang gemilang.

Preferensi ini dihasilkan dari proses penalaran yang mencakup psikologis orang tuanya sendiri, kepuasan dan rekonsiliasi kepercayaan sejarah kuno dalam era modern. 
Ditinjau dari values of child, terdapat beberapa komponen yang menunjukkan bahwa orang tua yang menjadi sampel penelitian membutuhkan anak yang berkualitas sama artinya dengan orang tua membutuhkan anaknya untuk mencapai sesuatu dalam hidupnya yang masuk dalam kategori Achievement, competence, creativity. Orang tua juga menginginkan supaya anaknya mempunyai masa depan yang gemilang dan mampu menjaga orang tuanya hingga hari tua yang masuk dalam kategori economic utility, security in old age

Dalam jurnal "Do Dragon Have Better Fate?" oleh Ka-Fu Wong dan Linda Yung (2005), dijelaskan bahwa secara tradisional, masyarakat Cina percaya bahwa waktu kelahiran seseorang sesuai dengan tanda zodiak Cina menentukan nasib orang tersebut. Berdasarkan keyakinan ini, banyak orang tua yang merencanakan kelahiran anaknya sesuai dengan zodiak Cina untuk memberikan "modal tambahan" untuk keberhasilan anak.

Dalam Forbes Magazine (1 November 2002) melaporkan bahwa 43 dari 400 (11\% dari $100 \%)$ pengusaha terkaya lahir di tahun naga, sehingga membuat tahun naga menjadi tahun yang paling banyak mempunyai orang yang sukses. Artikel semacam itu semakin mendukung keyakinan bahwa anak yang lahir di tahun naga memiliki keberuntungan yang lebih baik yang menunjukkan bahwa mereka lebih beruntung dan lebih mampu menggunakan modal tambahan untuk menjadi lebih produktif dibandingkan dengan orang yang lahir di tahun lain. Penelitian menggunakan Hongkong Census Data pada tahun 1991 dan tahun 1996.

Dengan data tersebut, tidak ditemukan bukti yang kuat dan mampu menunjukkan bahwa orang yang lahir di tahun naga dan masuk ke dalam Hongkong Census Data mempunyai nasib yang lebih baik, karena secara statistik ekonomis mempunyai data yang tidak stabil.

Ditinjau dari values of child, terdapat beberapa komponen yang menunjukkan bahwa orang tua yang menjadi sampel penelitian membutuhkan anak yang lebih beruntung yang sama artinya bahwa orang tua membutuhkan 
anak yang mampu mencapai sesuatu terlebih karena anak tersebut dilahirkan di tahun naga sehingga masuk dalam kategori achievement, competence, creativity.

\section{Kesimpulan \& Saran}

Penelitian literatur ini termasuk dalam penelitian psikologi budaya. Isi penelitian literatur ini mengenai mitos zodiak Cina yang disebut shio yang merupakan nilai dan telah menjadi keyakinan yang mampu mempengaruhi sesuai teori values of children. Selain itu, dalam penelitian literatur ini juga akan membahas hasil penelitian yang akan dikategorikan dalam profil values of children. Penelitian literatur seperti ini masih sangat jarang dilakukan sehingga diharapkan hal ini dapat memberikan kontribusi baru sebagai salah satu kajian alternatif yang bisa digunakan untuk penelitian selanjutnya.

Hasil penelitian secara literatur menunjukkan values of children yang muncul dari orang tua yang mmiliki anak di tahun naga meliputi power, influence, effectiveness, social comparison, economic utility, security in old age, achievement, competence, creativity.

Berdasarkan hasil, dapat diketahui karakter orang tua yang memiliki anak di tahun naga menggambarkan nilai anak dalam kelompok nilai secara psikologis , sosial dan ekonomis. Kelompok psikologis menggambarkan pada manfaat secara psikologi saat mempunyai anak seperti sukacita, kesenangan, persahabatan, kebanggaan atau rasa pencapaian yang diperoleh orang tua dalam memiliki anak, yang termasuk dalam kelompok psikologis adalah kategori expansion of the self, ties to a larger entity and immortality, morality, primary group tie dan stimulation, novely and fun.

Untuk kelompok sosial menggambarkan pada penerimaan sosial yang dinikmati orang tua ketika memiliki anak. Kategori yang masuk dalam kelompok sosial adalah adult status \& social identity, achievement, competence, creativity, power, influence, effectiveness dan social comparison.

Untuk kelompok ekonomis termasuk pada materi anak baik saat muda ataupun saat dewasa. Yang pada akhirnya menjadi bentuk jaminan bagi orang tua berkaitan dengan kontribusi anak terhadap ekonomi rumah tangga dan pekerjaan Jurnal Insight Fakultas Psikologi Universitas Muhammadiyah Jember | 121 
rumah tangga. Yang termasuk dalam kelompok ekonomis adalah economic utility, security in old age. Untuk profil orang tua dalam penelitian menunjukkan kecenderungan untuk memiliki anak yang lahir di tahun naga ditinjau dari values of children dalam kelompok sosial (achievement, competence, creativity, power, influence, effectiveness dan social comparison) dan kelompok ekonomis (economic utility, security in old age).

Untuk penelitian selanjutnya, diharapkan mampu melakukan penelitian dengan jurnal yang lebih banyak dan lebih kompleks sehingga dapat berkontribusi secara maksimal terhadap values of children bagi orang- orang yang percaya dengan shio. Terlebih dapat dilakukan lebih banyak penelitian akan hubungan antara shio dan masyarakat selain shio naga.

\section{DAFTAR PUSTAKA}

Goodkind, D.M., (1991). Creating new traditions in modern Chinese populations: aiming for birth in the year of the dragon. Population and Development Review 17, 663-686.

Johnson. N.D, Nye. J.V.C. (2010). Does Fortune Favor Dragons? , Journal of Economic Behavior \& Organization, 85-97

Malinowski .B. (2014), Myth in Primitive Psychology

Yahyazade.M.(2013). Myth from a Psychological Point of View. Journal of Arts and Humanities, 67-73

Pan.G. Socio-biological Implications of Confucianism. Springer

Rèn, Qǔliàng (2007). Common Knowledge about Chinese Culture. Hongkong: Xiānggăng zhōngguó lüyóu chūbănshè

Rogers. P, Soule. J. (2009). Cross- Cultural Differences in the Acceptance of Barnum Profiles Supposedly Derived From Western Versus Chinese Astrology. Journal of Cross Cultural Psychology. 40.(03). 381-399

Santosa (2018), Buku Lengkap Shio \& Feng Shui : Laksana

Schwartz. Schwartz. S.H. (2006) Basic human values: Theory, measurement, and applications. Revue française de sociologie 
Schwartz (2018). Basic Human Values : An Overview

Wong. K, Yung.L, R. (2005), 'Do Dragons Have Better Fate, Journal of Economic Inquiry, 43 (3), 689-697.

Yip.P.S.F, Lee. J., Cheung Y.B. (2002). The Influence of the Chinese Zodiac on Fertility in Hong Kong SAR. Journal of Social Science \& Medicine (55), $1803-1812$

Zhúo, Bóhóng dan Guō, Jùnfēng. (2005). Shí’èr shēngxiōo yǔ zhōngguó wénhuà cóngshū. Jǐná : Jǔlǔ shūshè 